\title{
Molecular, Functional, and Pharmacological Characterization of the Metabotropic Glutamate Receptor Type 5 Splice Variants: Comparison with mGluR1
}

\author{
Cécile Joly, Jesus Gomeza, ${ }^{1}$ Isabelle Brabet, ${ }^{1}$ Kenneth Curry, ${ }^{2}$ Joël Bockaert, ${ }^{1}$ and Jean-Philippe Pin ${ }^{1}$ \\ 'Mécanismes Moléculaires des Communications Cellulaires UPR 9023, CNRS CCIPE, 34094 Montpellier Cedex 05, \\ France and ${ }^{2}$ The University of British Columbia, Department of Physiology, Vancouver, Canada V6T 1W5
}

\begin{abstract}
The main excitatory neurotransmitter in the brain, glutamate (Glu), activates not only receptor-channels, but also receptors coupled to G-protein called metabotropic Glu receptors (mGluRs). Eight genes coding for mGluRs have been characterized to date giving rise to even more proteins due to alternative splicing phenomena. Here we characterized a splice variant of mGluR5, called mGluR5b which contains a 32 amino acid fragment inserted in the cytoplasmic tail, 50 residues after the 7 th transmembrane domain. mGluR5b mRNAs are present in different regions of the adult rat brain and are expressed at a higher level than mGluR5a mRNA. Functional analysis of mGluR5a and mGluR5b revealed that they share all the properties of mGluR1a, but not those of mGluR1b or 1c. Like mGluR1a, both mGluR5a and mGluR5b activate a rapid and transient current in Xenopus oocytes. When expressed in LLC-PK1 cells, they show the same subcellular distribution as mGluR1a, and stimulate both inositol phosphate (IP) and cAMP production. Moreover, cells expressing mGluR5a or mGluR5b, like those expressing mGluR1a have a higher basal PLC activity that is not inhibited by glutamate-pyruvate transaminase (GPT), suggesting that these receptors have an intrinsic activity. Interestingly, the pharmacological profiles of mGluR5a and $b$ are identical, but different from that of mGluR1a. Most agonists, except glutamate, are more potent on mGluR5a/b than on mGluR1a. Interestingly, the mGluR1a antagonists MCPG and 4CPG have no effect on mGluR5a/b; 4C3HPG which is a full antagonist at mGluR1a is a partial agonist at mGluR5a/b. These results indicate that the long $\mathrm{C}$-terminal intracellular domain present only in mGluR1a and mGluR5a/b, although not well
\end{abstract}

\footnotetext{
Received Sept. 6, 1994; revised Nov. 28, 1994; accepted Jan. 3, 1994

This work was supported by grants from the CNRS, CEE (BIO2-CT930243). DRET (91/161) the Human Frontiers Science Program (RG 5792B). and Bayer Company (Germany). This work has been dunte as part of the BioAvenin program supported by Rhone-Poulenc with the participation of the French Ministry of Research and the French Ministry of Industry. J.G. was supported by an IPSEN and then a Spanish government fellowships. We thank Drs. L. Journot and B. Chini for critical reading of the manuscript, Dr. M. Lafon-Cazal for the determination of the Glu concentrations, Dr. D. Joubert for her help in the confocal microscope experiments, and Dr. C. Romano for the gift of the mGluR5 antibody Confocal microscopy experiments have been realized using the facilities of the Centre Régional d'Imagerie Cellulaire (C.R.I.C.). We thank also M. Passama and L. Charvet for their help in the iconography.

Correspondence should be addressed to Dr. Jean-Philippe Pin, Mécanismes Moléculaires des Communications Cellulaires, UPR 9023-CNRS, CCIPE, Rue de la Cardonille 34094 Montpellier Cedex 05. France.

Copyright ( 1995 Society for Neuroscience $0270-6474 / 95 / 153970-12 \$ 05.00 / 0$
}

conserved, is likely to be involved in the specific functional properties of these receptors. Although the ligand recognition sites of mGluR5a/b and mGluR1a are highly conserved, these receptors have different pharmacology.

[Key words: metabotropic glutamate receptors (mGluR), alternative splicing, G-protein, phospholipase $C$, Xenopus oocytes]

To mediate fast excitatory neurotransmission in the brain, glutamate (Glu) activates different subtypes of receptor-channels called NMDA, $\alpha$-amino-3-hydroxy-5-methylisoxazole-4-propionate (AMPA) and kainate receptors (Monaghan et al., 1989; Hollmann and Heinemann, 1994). Glu also activates G-protein coupled receptors called metabotropic Glu receptors (mGluRs) that modulate the activity of enzymes producing second messengers such as phospholipase C (PLC), adenylyl cyclase, and phospholipase A2 (PLA2). They also activate or inhibit ion channels such as voltage-sensitive $\mathrm{Ca}^{2-}$ and $\mathrm{K}^{+}$channels. Moreover, they modulate the activity of ligand-gated channels such as the GABA-A, AMPA, and NMDA receptors. Activation of mGluRs can therefore modulate and even mediate Glu-ergic neurotransmission in the brain (for a review, see Pin and Duvoisin, 1995).

Cloning of cDNA encoding mGluRs revealed a large family of receptors having no sequence homology with any other known G-protein coupled receptors (GPCR) (Houamed et al., 1991; Masu et al., 1991; Abe et al., 1992; Tanabe et al., 1992; Nakajima et al., 1993; Okamoto et al., 1994; Saugstad et al., 1994). To date eight genes coding for mGluRs have been described, giving rise to mGluR1 to 8 (for a review, see Pin and Duvoisin, 1995). Based on their amino acid sequence identity, pharmacology, and transduction mechanisms, they can be subclassified into three groups. mGluR1 and mGluR5 which represent the first group, are coupled to PLC, and have Quis as their most potent agonist. The 2nd group is composed of mGluR2 and mGluR3 which inhibit adenylyl cyclase and have (2S, $1^{\prime} \mathrm{S}, 2^{\prime} \mathrm{S}$ ) 2-(carboxycyclopropyl)glycine (L-CCG-I) as their Inost potent agonist. The others, mGluR4, 6, 7, and 8 correspond to the 3rd group, they also inhibit adenylyl cyclase but are selectively activated by L-amino-4-phosphonobutyrate (L-AP4). Multiplicity in this receptor family is augmented by the existence of splice variants. In the case of mGluRI, three splice variants called mGluR1a to $1 \mathrm{c}$ have been described. In mGluR $1 \mathrm{~b}$, the insertion of an additional 85 base pair exon, which contains an in frame stop codon, results in the deletion of 318 amino acids from the proposed cytoplasmic carboxy- 
terminal domain and 20 different residues at the carboxy-terminal tail (Tanabe et al., 1992). In mGluR lc a distinct insertion at the same position results in a similar deletion and 11 other amino acids at the carboxy-terminus (Pin et al., 1992). Functional analysis of these splice variants in either Xenopus oocytes or baby hamster kidney (BHK) cells revealed that all activate PLC (Pin et al., 1992; Pickering et al., 1993). However, the $\mathrm{Ca}^{2+}$ signal generated by the shorter proteins mGluR $1 b$ and mGluR $1 \mathrm{c}$ have a slower kinetic (Pin et al., 1992; Simoncini et al., 1993). Moreover, in contrast to mGluR la, mGluR $1 \mathrm{~b}$ seems to activate preferentially pertussis toxin (PTX)-insensitive G-proteins, and does not potentially activate adenylyl cyclase (Pickering et al., 1993). Finally, the subcellular distribution of mGluR la and $b$ expressed in BHK cells are different (Pickering et al., 1993).

Since mGluR5 is highly homologous to mGluR1, we looked for similar splice variants using the PCR technology and screening of rat brain cDNA libraries. We found a variant containing a 96 bp cassette inserted downstream of the 7 transmembrane domain (TMD) region. The sequence of a PCR product corresponding to mGluR5b has recently been published (Minakami et al., 1993), but neither the brain localization nor the function of this splice variant have been described. In the present study we show that mGluR5b is likely to be generated by alternative splicing, and show that both mGluR5 variants are present in different brain regions. A comparison of the function of mGluR5a, mGluR5b, and mGluR la revealed no apparent difference in their transduction mechanism and subcellular localization in transfected cells, but revealed interesting pharmacological differences between mGluR5a/b and mGluR 1 .

\section{Materials and Methods}

Cloning of mGluR5a and mGluR5b cDNA. A set of primers was used to amplify the cDNA fragment coding for the entire C-terminal intracellular domain of mGluR5. The sense primer MGR5-I (5'-GTG CGC AGC GCC TTC ACA ACC TCT AC-3') is located upstream of an Sphl site, corresponding to position 2494-2519 (Abe et al., 1992). The antisense primer corresponds to the $3^{\prime}$ end of the untranslated region of the published mGluR5 sequence: MGR5-2, 5'-CTC ATG TCT AGA CCG TGT GTG TCC TTG GC-3'; italicized in MGR5-2 is an Xbal site included to facilitate subcloning of the PCR products. DNA prepared from a rat forebrain random primed cDNA library constructed in the lambda Zap vector (generous gift of Dr. Jane Sullivan) was used as template. A single band of about $1200 \mathrm{bp}$ was obtained after 40 cycles of amplification (denaturation at $94^{\circ} \mathrm{C}$ for $30 \mathrm{sec}$, annealing at $60^{\circ} \mathrm{C}$ for $30 \mathrm{sec}$ and elongation at $72^{\circ} \mathrm{C}$ for $90 \mathrm{sec}$ ). After subcloning into the pBluescript vector the PCR fragments were subjected to restriction map analysis. Among the eight clones analyzed, six had a BgIII-SphI fragment longer by about $100 \mathrm{bp}$ than expected according to the published mGluR5 sequence. DNA sequencing using the dideoxynucleotide method and sequenase (U.S. Biochemicals) revealed the presence of an insertion of a 96 bp fragment in these clones.

To obtain full length mGluR5a and mGluR5b cDNA, a rat forebrain random primed cDNA library $(500,000$ clones) was screened at high stringency using as a probe the MGluk5 PCK product obtained as described above. The plasmid were rescued from the positive clones according to the manufacturer protocol and subjected to restriction map analysis. Clone B6 was found to contain most of the coding sequence of mGluR5 with the $96 \mathrm{bp}$ insertion characteristic of mGluR5b. Its 5' end corresponds to position 399. The mGluR.5 3' end was obtained by PCR using the oligonucleotides MGR5-1S (5'-TCT TTA TTA GCT TGA ATT CCT TTC C- $3^{\prime}$ ) and MGR5-11 AS (5'-ATC TTT GAA AGC CTC CAT CCC $3^{\prime}$ ) as primers and subcloned into pB6 after digestion with EcoRI and Ncol. The full length mGluR5a and $b$ cDNAs were constructed using the PCR fragments corresponding to the C-terminal domain of mGluR5a and mGluR5b obtained as described above. The sequence of DNA fragments obtained by PCR were verified using the dideoxynucleotide method and Sequenase (U.S. Biochemicals).

Partial characterization of mGiluR5 gene. Genomic southern blots were performed using $10 \mu \mathrm{g}$ of digested rat DNA per lane. Random primed synthesis of the radioactive probe and high stringency hybridization were carried using conventional methods.

A rat genomic library constructed in Lambda phages EMBL3 (Clonetech) was screened with the insert of clone $\mathrm{B} 6$ as a probe using conventional methods. Ten positives were isolated and analyzed. Lambda DNA was purified and analyzed using several restriction enzymes. After blotting and hybridization with mGluR5b cDNA, a single band of 4.5 $\mathrm{kb}$ was labeled in most cloned DNA digested with BamHI. After subcloning in the BamHI site of the pBluescript vector, this genomic fragment was subjected to restriction map analysis and partial sequencing.

In situ hybridization. In situ hybridization histochemistry was performed as described (Mengot et al., 1991). Briefly, Wistar rats (male, 200-300 gm) were killed by decapitation and the brains were quickly removed and frozen. Fifteen micrometer thick tissue sections were thaw mounted on gelatinized glass slides. The oligonucleotides specific for mGluR5a and mGluR5b mRNA (Bioprobe Systems, France) were complementary, respectively, to bases 2608-2647 (MGR5-19, 5'-TC ACA GAT TTT CCG TTG GAG CTT AGG GTT TCC. CCA GAG (IA-3') and to bases 2641-2680 located in the specific sequence of mGluR5b (MGR5-18, 5'-GG GTG AAA CAC TCT ATT TCC GAC TTG TGC TGG GCC AGT CT-3'). The oligomers were labeled at their $3^{\prime}$ end by the terminal transferase reaction with $\alpha^{3.3 P}$-dATP and shown to specifically label mGluR5a and mGluR5b cDNA on Southern blots, respectively. The in situ hybridization was carried out overnight at $42^{\circ} \mathrm{C}$ as described (Mengot et al., 1991), with 50\% formamide. Sections were then washed at $55^{\circ} \mathrm{C}$ in $1 \times \mathrm{SSC}(150 \mathrm{~mm} \mathrm{NaCl}, 15 \mathrm{~mm}$ Na citrate $(\mathrm{pH}$ 7.0) for $30 \mathrm{~min}$. Tissue sections were dehydrated and placed in contact with Hyperfilm beta-max (Amersham) for 2 weeks. We have not been able to obtain nice and specific signal with the oligonucleotide specific for mGluR5a (MGR5-19) (data not shown).

$R T$-PCR of $m G l u R 5 a$ and $m G l u R 5 b$. Total RNA were extracted from rat brain by conventional methods (Chomczynski and Sacchi, 1987). The reverse transcription reaction was conducted using $1 \mu \mathrm{g}$ of total RNA with 50U M-MLV reverse transcriptase (GIBCO-Bethesda Research Labs) in a $20 \mu$ l reaction containing 100 pmol of nonamer random primers (Bioprobe Systems), $1 \mathrm{~mm}$ dNTP (Pharmacia), $10 \mathrm{~mm}$ DTT in the reaction buffer supplied by the manufacturer (GIBCO-Bethesda Research Labs). Following 10 min at room temperature to allow annealing of the random primers, the reaction was conducted at $42^{\circ} \mathrm{C}$ for $1 \mathrm{hr}$ and stopped by denaturation of the enzyme at $95^{\circ} \mathrm{C}$ for $10 \mathrm{~min}$. The PCR reaction was performed using $1 \mu$ l of the RT reaction, $2.5 \mathrm{U}$ of Taq DNA polymerase (Promega), $400 \mu \mathrm{M}$ dNTP, 50 pmol of each primer, in the PCR buffer supplied by the manufacturer (Promega) and supplemented with $\mathrm{MgCl} 2$ (3 mM). Reaction was as follows: denaturation at $94^{\circ} \mathrm{C}$ for 1 min followed by 35 cycles (denaturation at $94^{\circ} \mathrm{C}$ for $30 \mathrm{sec}$, annealing at $55^{\circ} \mathrm{C}$ for $30 \mathrm{sec}$ and elongation at $72^{\circ} \mathrm{C}$ for $30 \mathrm{sec}$ ). The oligonucleotides used were oligo 5-20 for the sense primer ( $5^{\prime}$ GTT TTT CAG TCA GCC TCA GTG CC-3') and oligo 5-21 for the antisense primer (5'-CGT TTG GTT GGG GTT CTC CTT CT-3').

$R N A$ transcription and expression in Xenopus oocytes. The preparation of oocytes and the in vitro synthesis of RNA transcripts from the cloned cDNA have been reported (Pin et al., 1992). The pmGR5a and pmGR5b were linearized with Xhol prior to sense-strand RNA transcription with T3 RNA polymerase; $10 \mathrm{ng}$ of each cRNA was injected per oocyte unless otherwise indicated. Recordings were performed in Barth's medium using the two electrode voltage-clamp technique (Axoclamp 2A) $35 \mathrm{~d}$ after injection. Data were recorded on a PC computer and analyzed using the pCl.AMP software.

Culture and transfection of LLC-PKI cells. Culture and electroporation of the porcine kidney epithelial cells LLC-PK1 were conducted as described (Spengler et al., 1993). Briefly, cells were cultured in DMEM (GIBCO-Bethesda Research Labs) supplemented with $10 \%$ fetal calf serum and antibiotics (penicillin and streptomycin $100 \mathrm{U} / \mathrm{ml}$ final). The cDNA encoding mGluR5a and mGluR5b were directionally subcloned into the eukaryotic expression vector pRK5 between the restriction sites EcoRI and XbaI of the poly-linker. These plasmids were named pRKG5a and pRKG5b, respectively. Electroporation was performed in a total volume of $300 \mu \mathrm{l}$ with $10 \mu \mathrm{g}$ of carrier DNA (plasmid DNA without insert), 200-600 ng of plasmid DNA and 10 million cells in electroporation buffer $\left(\mathrm{K}_{2} \mathrm{HPO}_{4}, 50 \mathrm{~mm}\right.$; $\mathrm{CH}_{3} \mathrm{COOK}, 20 \mathrm{~mm} ; \mathrm{KOH}$, $20 \mathrm{~mm}$ ). After electroporation ( $260 \mathrm{~V}, 960 \mu \mathrm{F}$, Bio-Rad gene pulser electroporator), cells were resuspended in DMEM supplemented with $10 \%$ fetal calf serum and antibiotics, and split in 12 well clusters (Falcon) (10 million cells per cluster).

Determination of IP accumulation. Determination of IP accumulation 
in transfected cells was performed as previously described (Manzoni et al., 1990). Eight to $10 \mathrm{hr}$ after electroporation, cells were washed and incubated for $12 \mathrm{hr}$ in DMEM-glutamax-I (GIBCO) containing $1 \mu \mathrm{Ci} /$ $\mathrm{ml}{ }^{3} \mathrm{H}$-myo-inositol (23.4 Ci/mol; New England Nuclear). Cells were then washed three times and incubated for $1-2 \mathrm{hr}$ at $37^{\circ} \mathrm{C}$ in $1 \mathrm{ml}$ of HEPES buffer saline $\left(\mathrm{NaCl} 146 \mathrm{~mm}, \mathrm{KCl} 4.2 \mathrm{~mm}, \mathrm{MgCl}_{2} 0.5 \mathrm{~mm}\right.$, glucose $0.1 \%$, HEPES $20 \mathrm{~mm} / \mathrm{pH} 7.4$ ). Cells were then washed again twice with the same medium and preincubated for $10 \mathrm{~min}$ in medium containing $10 \mathrm{~mm} \mathrm{LiCl}$. Agonist was then added for a period of $30 \mathrm{~min}$. The reaction was stopped by replacing the incubation medium with 1 $\mathrm{ml}$ perchloric acid $(5 \%)$, on ice. The total IP were then extracted and purified on Dowex columns as previously described (Manzoni et al., 1990). Total radioactivity remaining in the membrane fraction was counted after solubilization in $10 \%$ Triton $\mathrm{X}-100,0.1 \mathrm{~N} \mathrm{NaOH}$ and used as standard. Results are expressed as the amount of IP produced over the radioactivity present in the membranes.

Determination of cAMP accumulation. The cellular cAMP production was measured using the prelabeling technique as previously described (Prézeau et al., 1994). Eight to $10 \mathrm{hr}$ after being electroporated, cells were washed and incubated for $12 \mathrm{hr}$ in DMEM-glutamax-I containing $1 \mu \mathrm{Ci} / \mathrm{ml}{ }^{2} \mathrm{H}$-adenine $(24 \mathrm{Ci} / \mathrm{mol})$. Cells were then washed three times and incubated for $1.5 \mathrm{hr}$ at $37^{\circ} \mathrm{C}$ in $1 \mathrm{ml}$ of HEPES buffer saline. Cells were then washed again twice with the same medium containing 0.75 mM IBMX and then stimulated for $10 \mathrm{~min}$ with $1 \mathrm{~mm}$ Glu. The reaction was stopped by aspiration of the media and addition of $1 \mathrm{ml}$ ice-cold $5 \%$ trichloroacetic acid. Cells were scraped and $100 \mu \mathrm{l}$ of $10 \mathrm{mM}$ ATP and $10 \mathrm{mM}$ cAMP were added to the mixture. Cellular proteins were removed by centrifugation at $5000 \times g$ and ${ }^{3} \mathrm{H}$-ATP and ${ }^{3} \mathrm{H}$-cAMP were separated by sequential chromatography on Dowex and alumina columns. cAMP formation is expressed as percentage conversion of ${ }^{3} \mathrm{H}$ ATP to ${ }^{3} \mathrm{H}$-cAMP: $\left({ }^{3} \mathrm{H}-\mathrm{cAMP} \times 100\right) /\left({ }^{3} \mathrm{H}-\mathrm{cAMP}+{ }^{3} \mathrm{H}\right.$-ATP $)$.

Determination of Glu concentration. Glu concentration in the incubation medium was determined as previously described using precolumn derivatization with orthophthalaldehyde and separation on a reversed phase C18 IIPLC column (Pin et al., 1986).

Immunostaining and confocal microscope experiments. Immunostaining experiments were performed essentially as previously described (Didier et al., 1992). Briefly, cells grown on coverslips were fixed with $4 \%$ paraformaldehyde in $120 \mathrm{~mm}$ glucose for $20 \mathrm{~min}$ at room temperature. Coverslips were rinsed in $0.1 \mathrm{~m}$ glycine $(\mathrm{pH} \mathrm{7.4)}$ for $30 \mathrm{~min}$ and then permeabilized with $0.05 \%$ Triton $\mathrm{X}-100$ in phosphate buffer saline (PBS) for $10 \mathrm{~min}$. After washing with PBS containing $10 \%$ gelatin (PBS-gelatin), cells were incubated with the anti-mGluR5 antibody (1: 200 ) in PBS-gelatin buffer over night at $8^{\circ} \mathrm{C}$. The mGluR5 antibody (m5.12, generous gift of Dr. C. Romano, Washington University School of Medicine, Saint Louis, MO) was raised against a peptide corresponding to the 13 C-terminal residues of mGluR5 and was shown not to cross-react with mGluRla (Romano et al., 1994). Coverslips were washed three times, for 30 min with PBS-gelatin buffer and exposed to goat anti-rabbit IgG second antibody conjugated to rhodamine (Sigma, Lisle d'Abaud, France), 1:100 in PBS-gelatin buffer for 1-2 hr at room temperature. After washing with PBS-gelatin, coverslips were mounted on glass slides, and visualized with a Bio-Rad MRC 600 confocal microscope.

Materials. (1SR,3RS)-1-aminocyclopentane-1,3-dicarboxylate (tACPD), quisqualate, ibotenate, $(R S)$ - $\alpha$-methyl-4-carboxyphenylglycine (MCPG), (S)-4-carboxyphenylglycine (4CPG), (S)-4-carboxy-3-hydroxyphenylglycine (4C3HPG), (S)-3-hydroxyphenylglycine (3HPG) were obtained from Tocris Neuramin (UK). The four stereoisomers of ACPD, $1 S, 3 R$-ACPD, $1 R, 3 S$-ACPD, $1 S, 3 S$-ACPD, and $1 R, 3 R$-ACPD were synthesized as previously described (Curry et al., 1988).

\section{Results}

Using a PCR approach, we have identified a mGluR5 cDNA, called mGluR5b, that contains an additional sequence of $96 \mathrm{bp}$ inserted at position 2628 (position 1 corresponding to the first base of the open reading frame). This sequence is identical to that recently reported (Minakami et al., 1993). The mGluR5b inserted cassette contains no stop codon in frame, so that the mGluR5b protein is expected to contain 32 additional amino acids located in the cytoplasmic tail, 50 residues after the 7 th TMD (Fig. I). Interestingly, two putative phosphorylation sites, one for PKA and one for PKC, are present in this cassette. In a)

\section{mGluR5b}

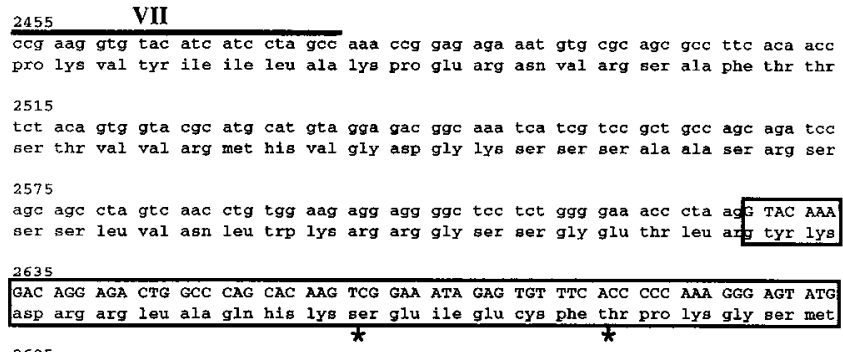
GGG AAT GGT GGG AGA GCA ACA ATG AGC Ade tco aac gga aaa tot gtg act tgg gc. ...

b)

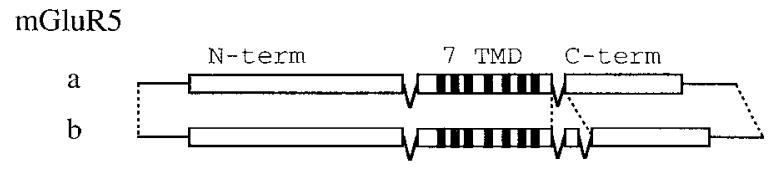

mGhuR1

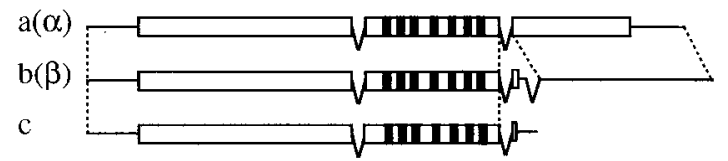

Figure 1. Nucleotide and amino acid sequence of mGluR5b $(a)$ and schematic representation of mGluR5 and mGluRI splice variants $(b)$. In $a$, the end of the 7th TMD is indicated $(V I I)$, and the sequence of the mGluR5b cassette is boxed. Putative phosphorylation sites are indicated $(*)$. Numbers on the left correspond to the hase number, number 1 being the first base of the initiation codon. $b$. The coding sequences are represented as open boxes whereas the noncoding sequences correspond to horizontal lines. The 7 TMD correspond to the solid squares. The identical sequences found in the different variants are joined by dashed lines. Only the introns that have been identified are presented.

contrast to mGluR $1 b$ and mGluR $1 \mathrm{c}$, mGluR5b protein still pos sesses a long C-terminal intracellular domain, like mGluR $1 \mathrm{a}$ and mGluR5a (Fig. 1).

It is likely that the mGluR5b cDNA is generated by alternative splicing of a single premessenger RNA for several reasons. First, Southern blots performed with rat genomic DNA digested with EcoRI or BamHI and hybridized with a radioactive probe corresponding to the 7 TMD region of $\mathrm{mGluR} 5$ revealed a single band (3.1 and $4.5 \mathrm{~kb}$, respectively), indicating that a single mGluR5 gene exists (data not shown). Second, screening of a rat genomic library with a mGluR5 probe allowed us to isolate a $20 \mathrm{kh}$ genomic clone. After digestion of this clone with BamHI, a single band of $4.5 \mathrm{~kb}$ hybridizes with mGluR5b cDNA used as a probe. This $4.5 \mathrm{~kb}$ fragment contains a single exon corresponding to the 7 TMD region of mGluR5 (Fig. 2). This exon ends exactly at the position were the mGluR5b cassette is inserted, and the following sequence in the mGluR5 gene corresponds to a splice donor consensus site. Interestingly, this exon corresponds almost exactly to its equivalent in the mGluR 1 gene (Fig. 2).

In order to verify that mGluR5b mRNA are present in the brain, mRNA isolated from different brain area were reversed transcribed and subjected to PCR amplification using oligonucleotide primers located on both side of the cassette. 'Ihese primers allow the amplification of both mGluR5a and mGluR5b 
mGluR5 gene

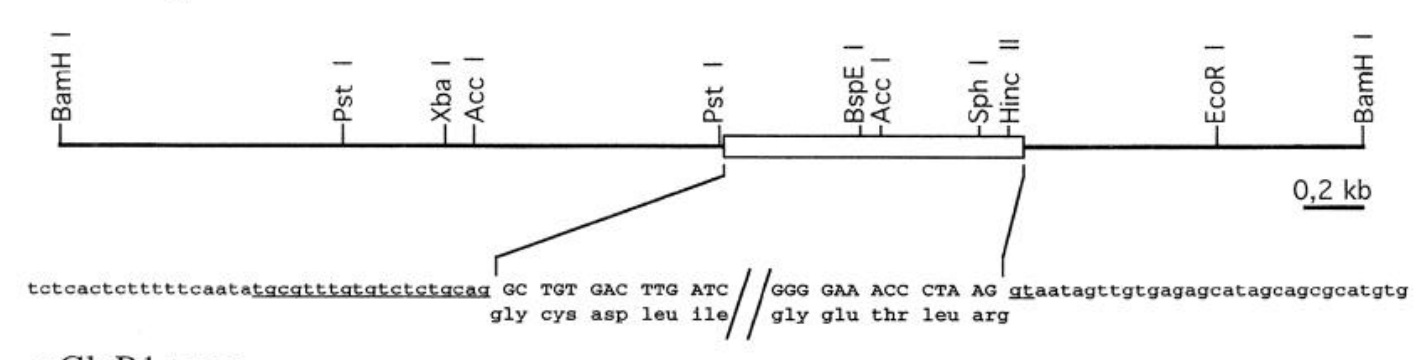

mGluR1 gene

agattctgattaaaatcattttttttctccttgCag GC TGT GAG CCC ATT//GCA GGG AAT GCC AA gtgagttgtctaatctggggttccaggtctct gly cys glu pro ile / ala gly asn ala asn

Figure 2. Partial characterization of mGluR5 gene. On the top is presented the restriction map of the genomic fragment containing the exon encoding the 7 TMD region of mGluR5 (open box). In the middle is presented the sequence at the intron-exon junctions; underlined are the splice acceptor and donor sites. For comparison, the homologous sequences in the mGluR1 gene are presented (from Houamed et al., 1991).

cDNA in a competitive manner, giving rise to two PCR products that have different size. The mGluR5b product ( $431 \mathrm{bp})$ is longer by 96 bp than the PCR product obtained from mGluR5a cDNA (335bp) (Fig. 3). In all brain regions examined, both products were obtained, whereas no amplification products could be detected when spleen RNA were used (Fig. 3). This indicates that both mGluR5a and mGluR5b mRNA are present in the brain. Moreover, since the amount of the PCR product corresponding to mGluR5b is always higher than that of mGluR5a, it is likely that the mRNA for mGluR5b is present at a higher density in the adult brain. The regional distribution of mGluR5b mRNA was examined by in situ hybridization using the mGluR5b specific oligonucleotide (Fig. 4). Intense labeling was found in the CA1 and CA 3 fields of the hippocampus, in the dentate gyrus, the striatum, the lateral septal nucleus and in the cortex (Fig. 4). This distribution corresponds exactly to that reported for mGluR5 mRNA, using a probe that did not discriminate between mGluR5a and mGluR5b mRNA (Abe et al., 1992).

The transduction mechanism of mGluR5b was first examined after expression of the receptor protein in Xenopus oocytes. In these cells, stimulation of PLC-coupled receptors leads to the activation of an oscillatory $\mathrm{Cl}^{-}$-current resulting from the release of $\mathrm{Ca}^{2+}$ from internal stores (Hirono et al., 1987). In these oocytes, mGluR la generates rapid and transient responses, whereas
mGluR $1 b$ and $c$ induce more slowly generating oscillatory responses (Pin et al., 1992). Like mGluRla, mGluR5a, and mGluR5b activate a current (Fig. 5) which reverses around -20 $\mathrm{mV}$ as expected for a $\mathrm{Cl}^{-}$-current in these cells (data not shown). Both mGluR5a and mGluR5b-mediated responses are transient, generate rapidly and are not followed by long lasting oscillations. As shown on Figure 5, the responses always peak during the first $15 \mathrm{sec}$, whatever the amount of cRNA injected into the oocytes. The time needed to reach the peak current is $6.27 \pm$ $0.37 \mathrm{sec}(n=111)$ and $5.39 \pm 0.32 \mathrm{sec}(n=138)$ for mGluR5a and mGluR5b respectively (means \pm SEM, values not statistically different). These values are $4.41 \pm 0.31(n=202)$ and $13.37 \pm 0.94(n=135)$ for mGluRla and mGluRlc respectively $(p<0.001)$. Both mGluR5a and mGluR5b mediated responses resemble therefore those generated by mGluRla.

Coupling of mGluR5a and mGluR5b to PLC was examined after transient expression into LLC-PK1 cells. Stimulation of cells expressing mGluR5a or mGluR5b with Glu results in a two- to threefold increase in the amount of IP (Fig. 6). This Glu effect was not observed on cells transfected with the carrier DNA alone. Surprisingly, the basal level of IP production in cells transfected with mGluR5a or mGluR5b is about twofold higher than that measured on control cells. Such an increase in basal PLC activity is also observed in cells expressing mGluR 1a

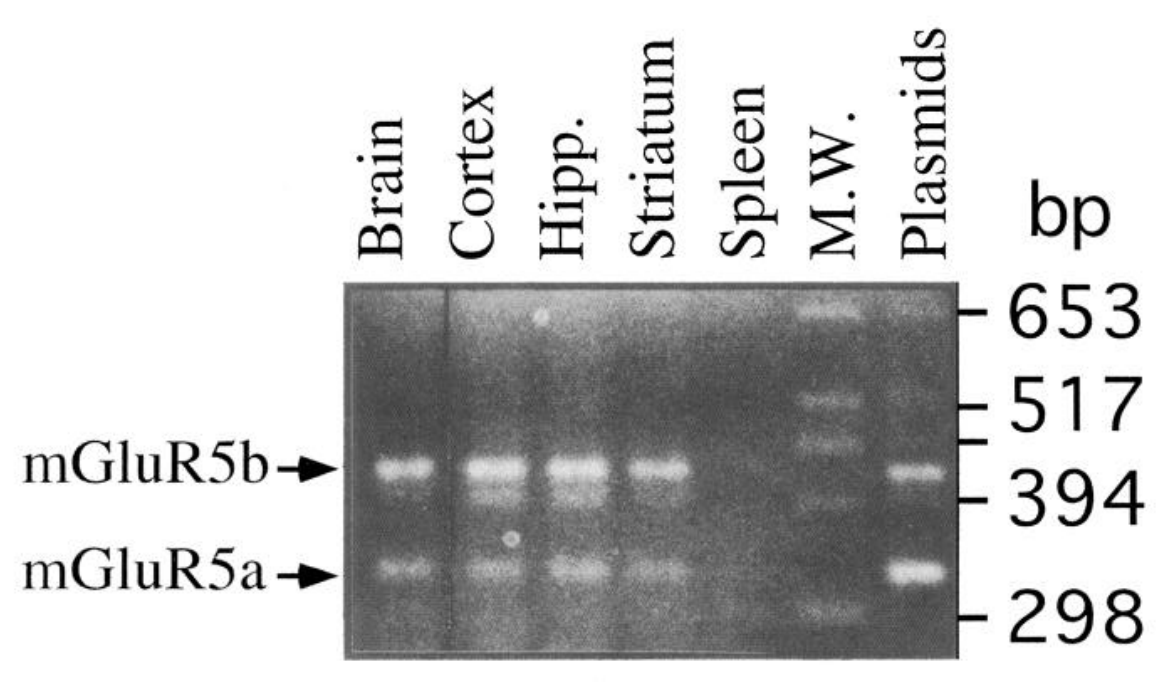

Figure 3. RT-PCR analysis of mGluR5a and b mRNA from different brain regions. Total RNA were prepared from different regions of the rat brain and spleen, reverse transcribed and used as template in a PCR reaction using primers annealing on both sides of the mGluR5b cassette. The size of the PCR products obtained from mGluR5a and mGluR5b cDNA is 335 and $431 \mathrm{bp}$, respectively. In the same experiment, $1 \mathrm{ng}$ of mGluR5a and mGluR5b plasmid DNA was also amplified (Plasmids). The additional band of about 400 bp visible in some lines has also been observed in some experiments when plasmid DNA is used as template, suggesting that it may rather correspond to a mispriming of the primers than to another variant of mGluR5. Hipp., Hippocampus; M.W., molecular weight markers. 


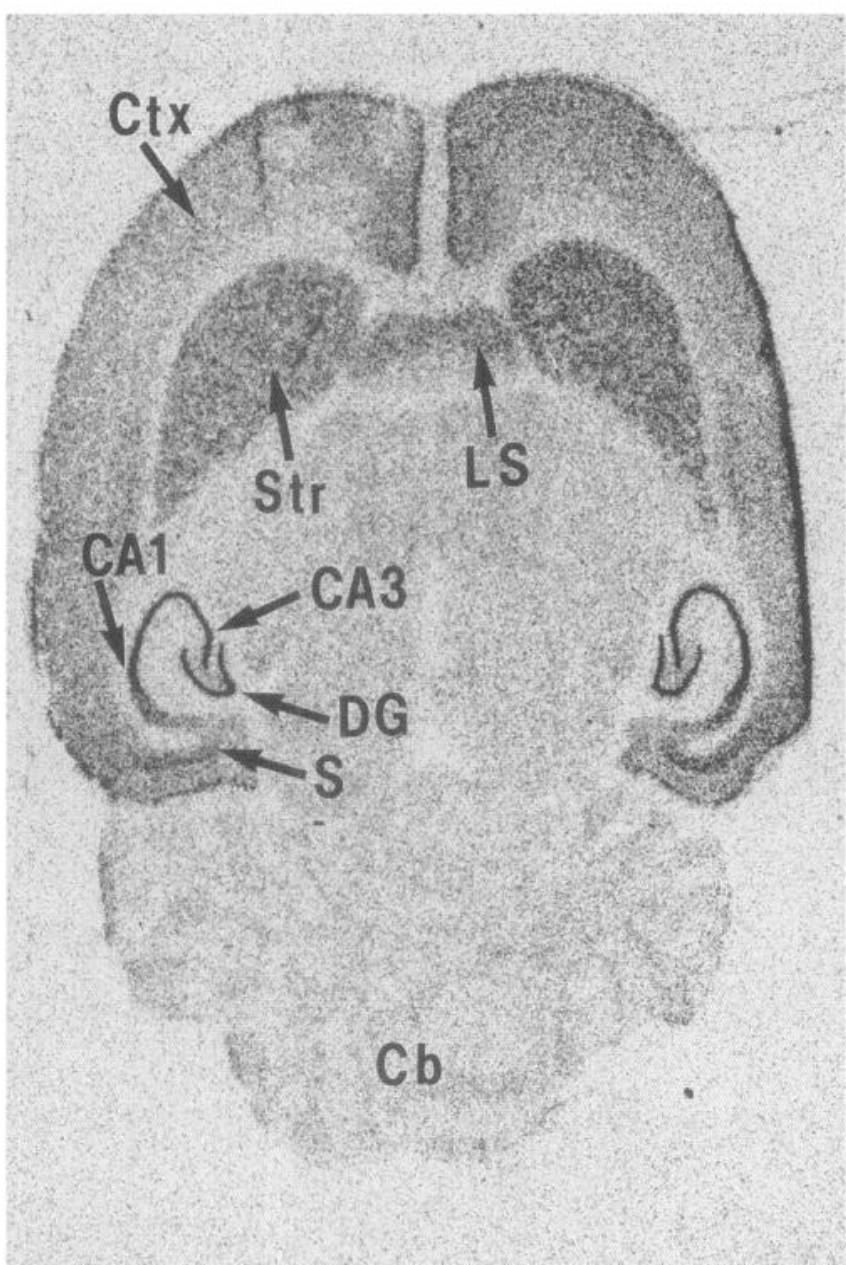

Figure 4. Localization of mGluR5b mRNA in the rat brain by in situ hybridization. An horizontal section of an adult rat brain was hybridized with a ${ }^{33} \mathrm{P}$-labeled oligonucleotide specific for mGluR5b, washed at high stringency and then autoradiographed. In the same experiment, no labeling was observed with a missense oligonucleotide or after treatment of the slice with RNases (not shown). CAl and CA3, CA1 and CA3 fields of the hippocampus; $C b$, cerebellum; $C t x$, cortex; $D G$, dentate gyrus; $L S$, lateral septum; $S$, subiculum; $S t r$, striatum.

but not in those expressing mGluR1b or c (unpublished observations). This basal activity is unlikely due to low concentrations of Glu present in the incubation medium since even after $1 \mathrm{hr}$ incubation with the cells, Glu concentration in the medium was found to be $0.3 \mu \mathrm{M}$, a concentration not sufficient to activate mGluR5 expressed in LLC-PK 1 cells (see Fig. 10) or in Xenopus oocytes (data not shown). Moreover, the basal activity is not inhibited by an enzyme degrading Glu, glutamate pyruvate transaminase in the presence of $2 \mathrm{~mm}$ pyruvate (Fig. 6). Taken together, these results suggest that both mGluR5a and mGluR5b, like mGluR la, are slightly active even in the absence of agonist.

Activation of adenylyl cyclase has been observed with mGluRla expressed either in Chinese hamster ovary (CHO) cells (Aramori and Nakanishi, 1992) or in baby hamster kidney (BHK) cells (Pickering et al., 1993). Similarly, Glu stimulates cAMP production in LLC-PK1 cells expressing mGluRla but not in those expressing mGluR1b (Fig. 7). In these cells, mGluR5a and mGluR5b also stimulate cAMP production (Fig. 7).
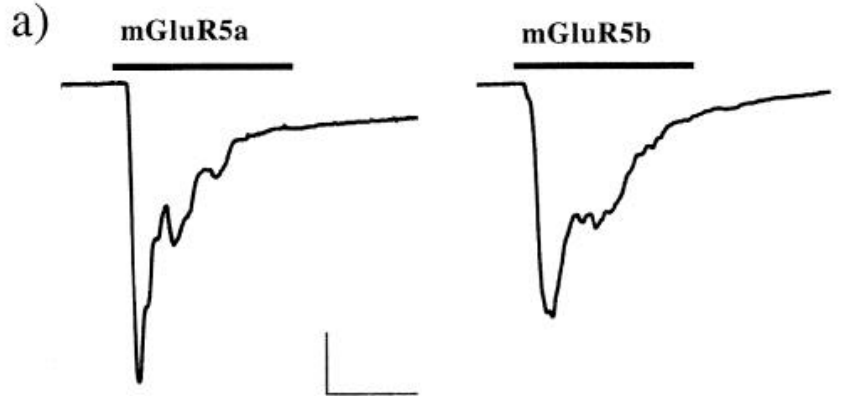

b)

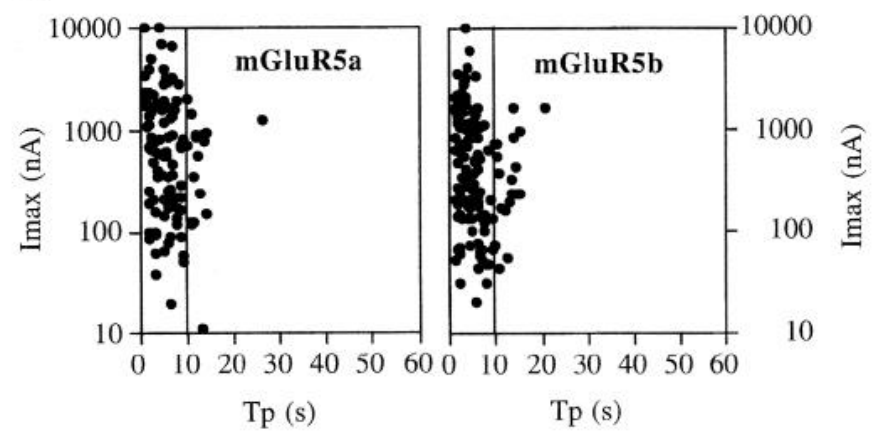

Figure 5. mGluR5a and mGluR5b activate a rapid and transient inward current when expressed into Xenopus oocytes. Three days after injection with in vitro synthesized RNA, Xenopus oocytes were voltage clamped at $-70 \mathrm{mV}$ and continuously perfused with Barth solution. $a$, Typical traces obtained in mGluR5a or mGluR5b expressing oocytes stimulated with $300 \mu \mathrm{M}$ Glu for $30 \mathrm{sec}$ (thick horizontal bar). Calibration bars are $15 \mathrm{sec}$ (horizontal bar) and $500 \mathrm{nA}$ (vertical bar). $b$, Plot of the maximal amplitude current $\left(I_{\max }\right)$ of each recorded traces as a function of the time to peak value $(T p)$ defined as the time needed to reach the maximal current after the response started. Each point represents a trace obtained from one oocyte injected with $0.5,1.0,5.0$, or $10.0 \mathrm{ng}$ of mGluR5a or mGluR5b cRNA. Data presented for mGluR5a and mGluR5b are from 111 and 138 oocytes, respectively.

Differences in the subcellular distribution of mGluR 1 a and mGluRlb expressed in BHK cells have been described (Pickering et al., 1993). Whereas the mGluR 1 a receptor proteins are localized to patches along the plasmalemma membranes and intracellularly around the nucleus, mGluRlb is distributed diffusely throughout the cell. Similar data where obtained when mGluR $1 \mathrm{a}$ and mGluR1b are expressed in LLC-PK1 cells (unpublished data). Immunofluorescence imaging of mGluR5a and mGluR5b expressing cells show intense labeling. As with mGluR la expressing cells, the staining is concentrated intracellularly around the nucleus (Fig. 8a,b) and can be seen as "wrinkles" on the top of the cells (Fig. $8 c, d$ ), and as patches along the plasma membrane contacting the plastic of the petri dish (Fig. $8 e-g$ ). No labeling of cells transfected with mGluR 1a (Fig. $8 h$ ) or carrier DNA alone (data not shown) was observed.

Since mGluR5b contains additional putative phosphorylation sites for PKC and PKA compared to mGluR5a, the effect of PKC and PKA activators on IP production stimulated by these receptors was examined. The PKC activator phorbol-dibutyrate $(\mathrm{PdBu})$ dose dependently inhibits Glu-induced IP production in cells expressing mGluR5a or mGluR5b (Fig. 9a,d). The maximal inhibition observed is close to $50 \%$, and the IC50 around $10 \mathrm{nM}$, in agreement with the reported potency of $\mathrm{PdBu}$ in activating PKC. The PKC inhibitor staurosporine has no effect on its own (Fig. 9b,e) but reversed the inhibition induced by $\mathrm{PdBu}$ indicating that the $\mathrm{PdBu}$ effect results from PKC activation (Fig. 


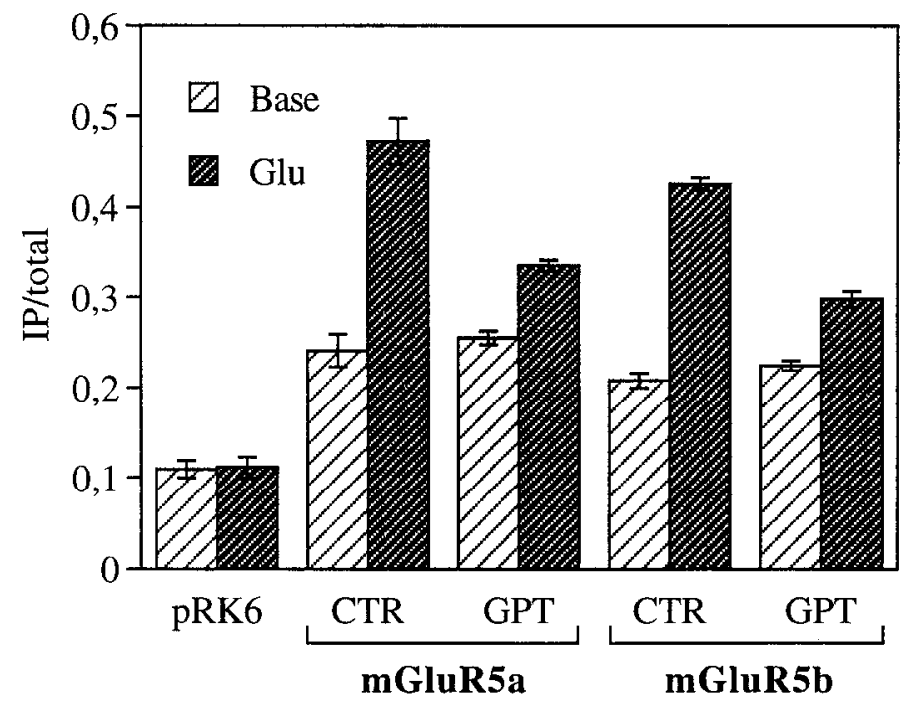

Figure 6. Stimulation of PLC by mGluR5a and mGluR5b in LLC. PKI cells. Cells were transfected with carrier DNA alone (pRK6) or with pRKG5a (mGluR5a) or pRKG5b (mGluR5b) and then labeled with ${ }^{3} \mathrm{H}$-inositol. After a $10 \mathrm{~min}$ incubation in Krebs' medium containing 10 $\mathrm{mm} \mathrm{LiCl}$, cells were incubated for a further $30 \mathrm{~min}$ in the same medium (Base) or after addition of $10 \times$ concentrated Glu solution ( $1 \mathrm{~mm}$ final concentration), in the absence (CTR) or in the presence (GPT) of 1 $\mathrm{U} / \mathrm{ml}$ glutamate-pyruvate transaminase and $2 \mathrm{~mm}$ sodium pyruvate. Results are expressed as the ratio of ${ }^{3} \mathrm{H}-\mathrm{IP}$ produced over total radioactivity in the membranes, and are means \pm SEM of triplicate determinations from a typical experiment.

$9 c, f)$. Similar effects of $\mathrm{PdBu}$ and staurosporine were observed on mGluR5a and mGluR5b stimulation of cAMP production (data not shown). The effect of activating PKA activity on the IP production stimulated by mGluR5a and mGluR5b was also examined. PKA activity was stimulated in different ways. First, adenylyl cyclase activity was stimulated by using either its direct activator forskolin, or vasopressin that activates $\mathrm{V} 2$ receptors present on these cells (Spengler et al, 1993). Second, the intracellular concentration of cAMP was increased using the phosphodiesterase inhibitor isobutylmethylxanthine (IBMX). Finally, direct activation of PKA with the membrane permeable analog of cAMP, 8Br-cAMP was used. None of these drugs modified the basal and the Glu stimulated IP production in cells expressing either mGluR5a or mGluR5b (data not shown).

The agonist pharmacological profile of mGluR5a and mGluR5b was compared to that of mGluR1a. On mGluR5a or mGluR5b, Quis was the most potent agonist, followed by Ibo, Glu, and t-ACPD (Fig. 10). No difference in the potency of these drugs on mGluR5a and mGluR5b can be noticed (Table 1). Interestingly, the pharmacological profile of these mGluR5 variants is slightly different from that of $\mathrm{mGluR} 1 \mathrm{a}$ expressed in the same cells. Quis, Ibo, and t-ACPD are 10, 5, and 2 times more potent on mGluR5 than on mGluRla, whereas Glu has about the same potency on these receptors (Table 1). t-ACPD is composed of two stereoisomers, $1 S, 3 R$-ACPD and $1 R, 3 S$-ACPD. Both isomers activate mGluRla, mGluR5a and mGluR5b, $1 S, 3 R$-ACPD being 10 times more potent than $1 R, 3 S$-ACPD (Table 1). Both isomers are more potent on mGluR5 than on mGluR la. The other isomers $1 S, 3 S-\mathrm{ACPD}$ and $1 R, 3 R-\mathrm{ACPD}$ are less active (Table 1).

Phenylglycine derivatives MCPG, 4CPG, and 4C3HPG are full competitive antagonists at mGluRla. However, MCPG and 4CPG ( $1 \mathrm{~mm}$ ) do not inhibit Glu $(10 \mu \mathrm{M})$ response on mGluR5a

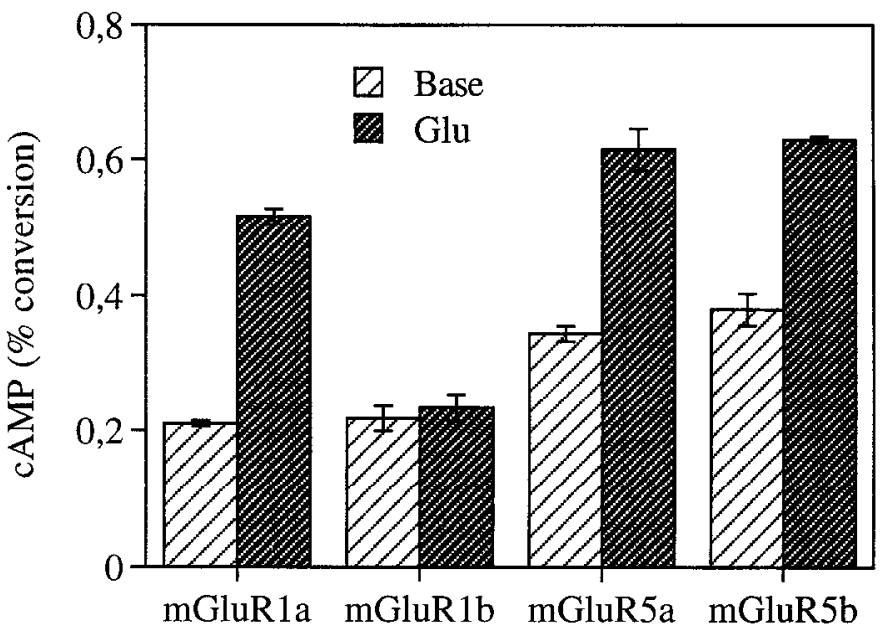

Figure 7. Stimulation of adenylyl cyclasc by mGluRs in LLC-PK 1 cells. Cells were transfected with pRKGla (mGluRla), pRKGlb $(m G l u R 1 b)$, pRKG5a (mGluR5a), or pRKG5b (mGluR5b) and then labeled with ${ }^{3} \mathrm{H}$-adenine. After a $10 \mathrm{~min}$ incubation in Krebs medium containing $10 \mathrm{~mm}$ IBMX. Cells were then incubated for a further 10 min in the same medium (Base, clear bars) or after addition of $10 \times$ concentrated Glu solution ( $1 \mathrm{~mm}$ final concentration, dark bars). Results are expressed as the percentage of conversion of ${ }^{3} \mathrm{H}$-ATP into ${ }^{3} \mathrm{H}$-cAMP, and are means \pm SEM of triplicate determinations from a typical experiment.

or mGluR5b expressing cells (Fig. 11a). Although 4C3HPG (1 $\mathrm{mm}$ ) slightly inhibits mGluR5 stimulation of PLC, it also stimulates IP production in both mGluR5a and mGluR5b expressing cells ( $\mathrm{EC}_{50} \geq 300 \mu \mathrm{M}$ ) suggesting that it acts as a partial agonist on these mGluR subtypes (Fig. 11 a). Under identical conditions, all these compounds antagonize Glu responses on mGluR la expressing cells (Fig. $11 b$ ). $3 \mathrm{HPG}$ which is a partial agonist at mGluRla $\left(\mathrm{EC}_{50}=100 \mu \mathrm{M}\right)$, is also a partial agonist at both mGluR5a and mGluR5b $\left(\mathrm{EC}_{50}=35 \mu \mathrm{M}\right)($ Fig. 11 $a, b)$.

\section{Discussion}

Recently, several splice variants for GPCR have been described (for a review, see Journot et al., 1994). Some of these variants are truncated receptors lacking transmembrane domains, and have generally no characterized function. In other cases, cassettes are inserted in the first or third intracellular loops, resulting in most cases in no major difference in the transduction mechanism, cxcept in the case of the PACAP-receptor (Spengler et al., 1993). A third type of GPCR splice variants corresponds to those having different $\mathrm{C}$-terminal domains. In the case of the prostaglandin EP3 receptor, changing the C-terminal domain generates receptors that have different transduction mechanisms (Namba et al., 1993; Sugimoto et al., 1993) and desensitization properties (Negishi et al., 1993). In the mGluR family, the shorter variants mGluR $1 \mathbf{b}$ and mGluR $1 c$ have some functional characteristics different from those of the longer protein mGluRla (Table 2), suggesting that this long $\mathrm{C}$-terminal domain may play some roles in the functional coupling to $\mathrm{G}$-proteins. Moreover, the N-terminal part of the C-terminal domain of mGluRl has been shown to play a critical role for its coupling to PLC (Pin et al., 1994).

In the present study, we show that the mGluR5b cDNA, whose sequence has recently been published (Minakami et al., 1993), is likely generated by alternative splicing of a unique mGluR5 gene. The expected mGluR5b protein contains a 32 

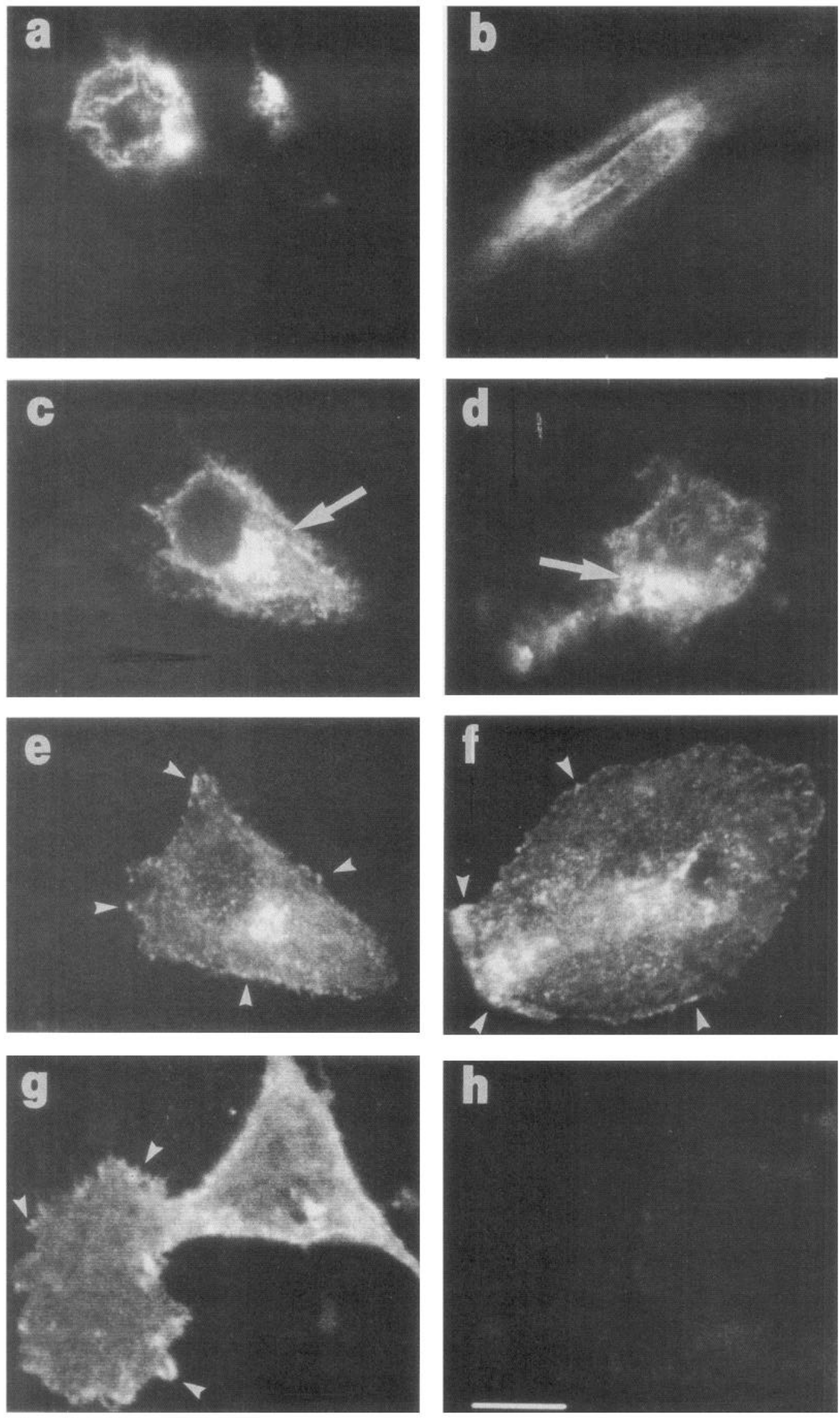

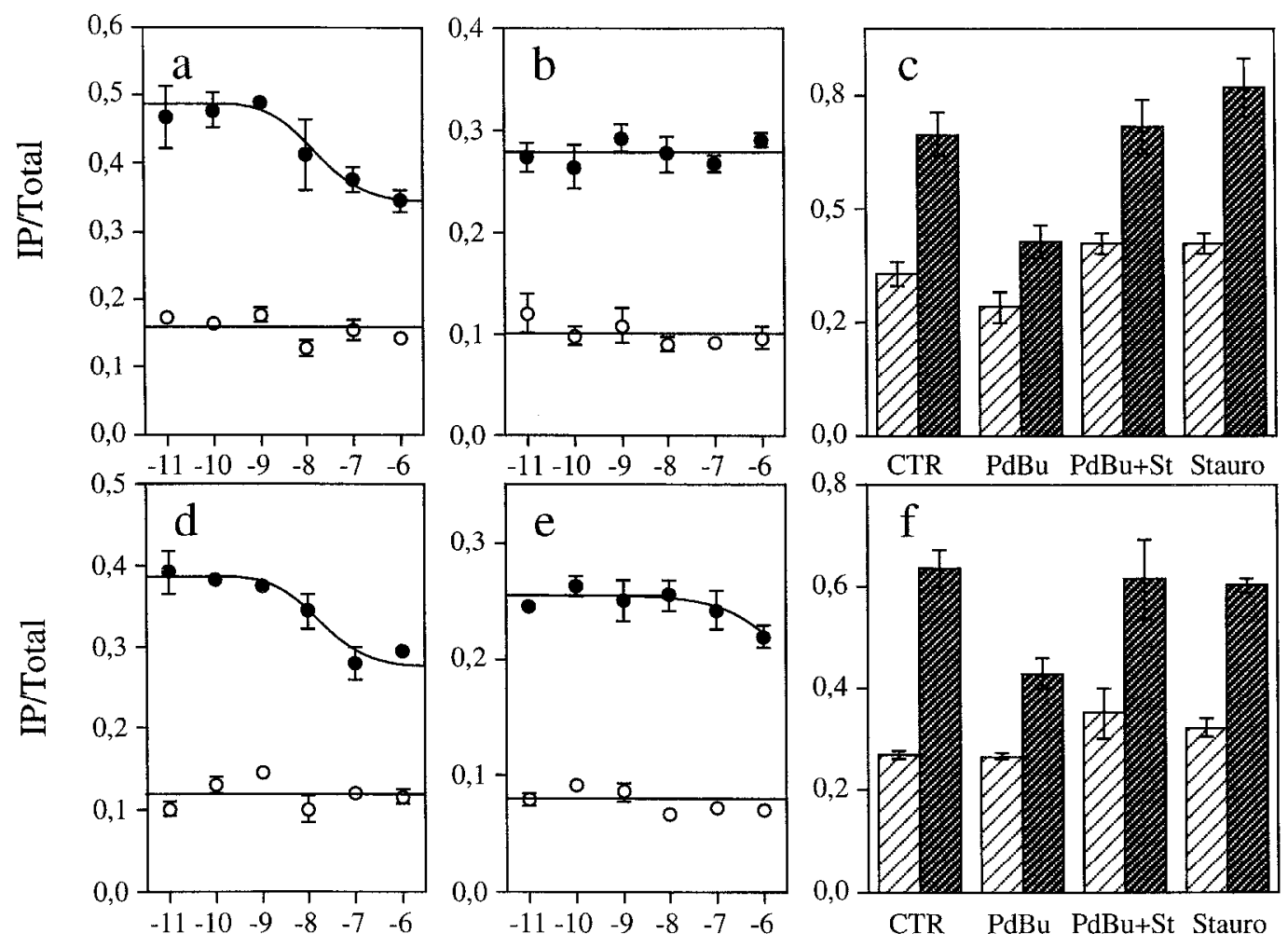

\section{$\log [\mathrm{PdBu}](\mathrm{M})$}
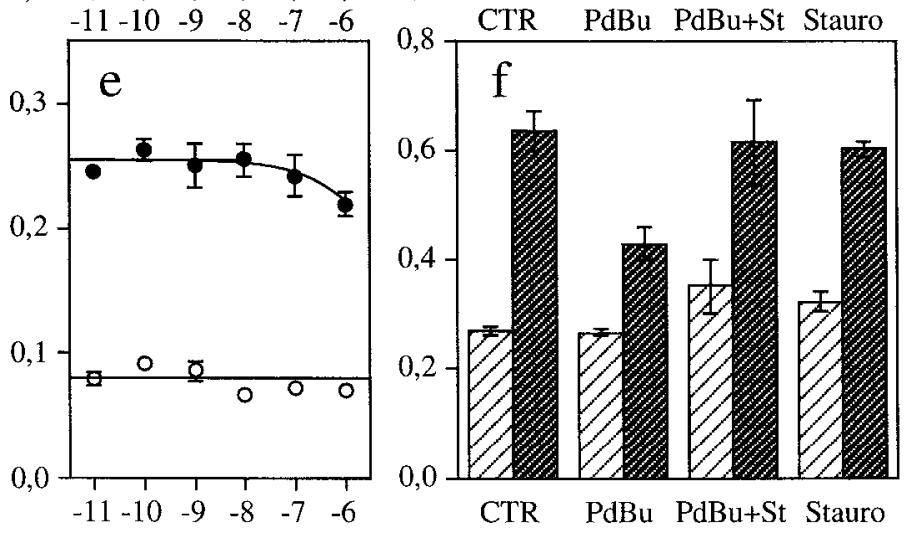

Figure 9. Effect of PKC activation on IP production by mGluR5a and mGluR5b. ${ }^{3} \mathrm{H}$-inositol-labeled LLC-PK1 cells transiently expressing mGluR5a $(a-c)$ or mGluR5b $(d-f)$, were preincubated for $10 \mathrm{~min}$ in Krebs' medium containing $10 \mathrm{~mm} \mathrm{LiCl}$ and the indicated concentration of $\operatorname{PdRu}(a, d)$, or staurosporine $(b, e)$. Cells were then incubated for a further $30 \mathrm{~min}$ in the same medium (open circles) or stimulated by adding $10 \times$ concentrated Glu solution ( $1 \mathrm{~mm}$ final; solid circles). In $c$ and $f$, cells were preincubated with Krebs' medium alone (CTR) or containing 300 nм PdBu $(P d B u), 300 \mathrm{~nm}$ staurosporine alone (Stauro) or with $300 \mathrm{~nm} \mathrm{PdBu}(P d B u+S t)$. Cells were then incubated for a further $30 \mathrm{~min}$ in the same medium (light bars) or stimulated by adding $10 \times$ concentrated Glu solution ( $1 \mathrm{~mm}$ final; dark bars). Results arc expressed as the ratio of ${ }^{3} \mathrm{H}-\mathrm{IP}$ produced over total radioactivity in the membranes, and are means \pm SEM of triplicate determinations from typical experiments.

amino acid insertion after the 7 th TMD. Therefore, in contrast to the truncated mGluR1 splice variants, mGluR $1 b$ and mGluR lc, the expected mGluR5b protein still possesses a very long C-terminal intracellular domain. Accordingly, the mGluR5b protein can be detected using an antibody directed against a peptide corresponding to the C-terminal end of mGluR5a.

RT-PCR analysis revealed that mGluR5b mRNA may be expressed at a higher level than mGluR5a mRNA in the adult brain. Accordingly, the distribution of the mGluR5b mRNA in the brain is identical to that already reported for mGluR5, using a nonselective probe (Abe et al., 1992). It is still possible that alternative splicing of mGluR 5 mRNA, as already described for mGluRl (Pin et al., 1992), may depend on the cell type analyzed so that mGluR5a and $b$ mRNA have slightly distinct distribution in the brain. To analyze this possibility, and due to the predominance of the mGluR5b mRNA, it is necessary to specifically localize mGluR5a mRNA. Unfortunately, the oligonucleotide which may specifically label mGluR5a did not allow us to obtain specific labeling. It is also possible that the distribution and the level of expression of each variant vary during development.

Our functional analysis of mGluR5a and mGluR5b revealed no difference in their coupling to PI C in either Xenopus oncytes or mammalian cells. Both receptors, like mGluR1a, induce a rapid and transient response in Xenopus oocytes. This indicates that they induce a rapid and transient $\mathrm{Ca}^{2+}$ signal since the activation of the $\mathrm{Cl}^{-}$-current has been shown to reflect nicely the variation in the intracellular $\mathrm{Ca}^{2+}$ concentrations (Lechleiter et al,, 1991). In LLC-PK1 cells, both receptors stimulate the production of IP when activated with Glu. Although mGluR5b contains two additional putative phosphorylation sites, one for $\mathrm{PKC}$ and one for PKA, both mGluR5a and mGluR5b coupling to PLC are diminished after PKC activation, and are not sensitive to PKA. It is possible that the inhibition of the IP production observed after $\mathrm{PKC}$ activation results from a downregulation of a component downstream of the receptor, such as PLC itself (Cockeroft and Thomas, 1992). Such an effect may mask a pu-

$\leftarrow$

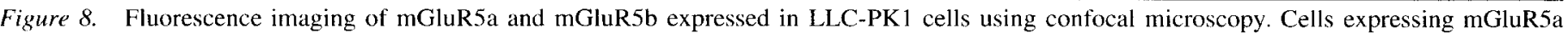

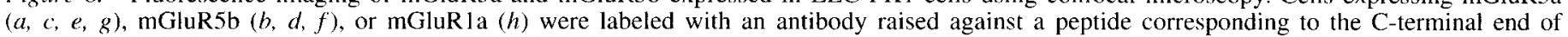

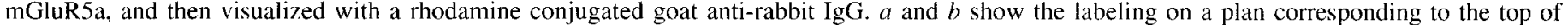

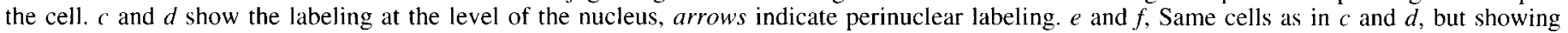

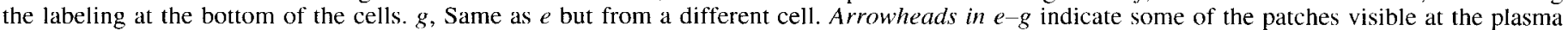
membrane level. Scale bar, $10 \mu \mathrm{m}$. 

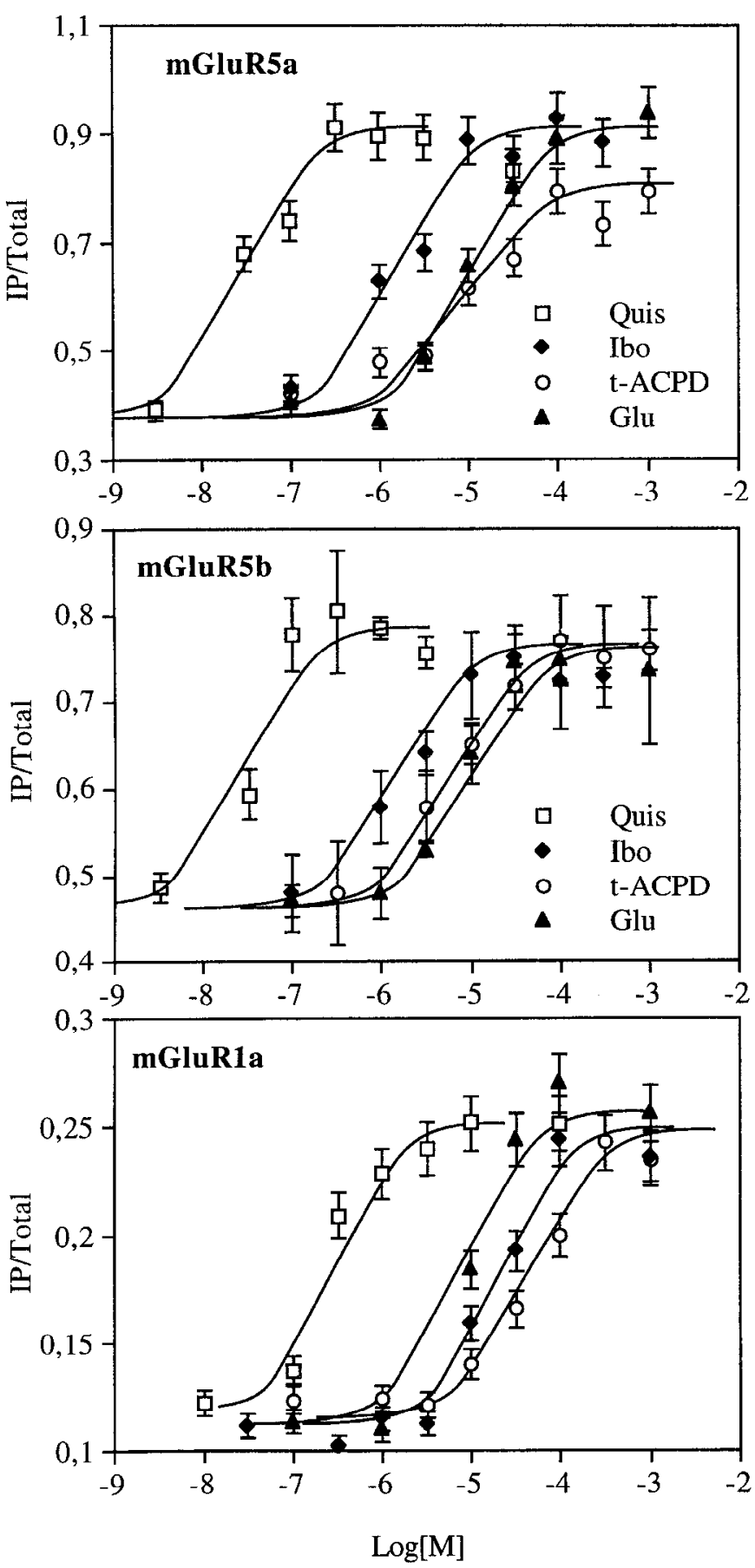

Figure 10. Agonist pharmacological profiles of mGluR5a, mGluR5b, and mGluR 1a expressed in LLC-PK1 cells. ${ }^{3} \mathrm{H}$-Inositol-labeled LLCPK 1 cells transiently expressing mGluRs were preincubated for $10 \mathrm{~min}$ in Krebs' medium containing $10 \mathrm{~mm} \mathrm{LiCl}$ and then stimulated with the indicated concentration of quisqualate (Quis, $\Pi)$, ibotenate $($ (lbo, $\downarrow)$, t-ACPD $(O)$, or Glu $(\Delta)$ for $30 \mathrm{~min}$. Results are expressed as the ratio of ${ }^{3} \mathrm{H}-\mathrm{IP}$ produced over total radioactivity remaining in the membranes, and are means \pm SEM of triplicate determinations from typical experiments.

tative direct effect of PKC on mGluR5b which cannot therefore be measured under our experimental conditions.

The basal PLC activity of LLC-PKl cells expressing mGluR5a or $b$ is higher than that measured in control cells. This is not due to residual Glu present in the buffer, since it has been
Table 1. $\mathrm{EC}_{50}$ values of different agonists at mGluR1a, mGluR5a, and mGluR5b

\begin{tabular}{lccc} 
& mGluR1a & mGluR5a & mGluR5b \\
\hline Glutamate & $12.36 \pm 2.75$ & $9.75 \pm 0.25$ & $7.67 \pm 1.20$ \\
Quisqualate & $0.26 \pm 0.04$ & $0.022 \pm 0.004$ & $0.047 \pm 0.018$ \\
Ibotenate & $11.3 \pm 1.8$ & $2.87 \pm 1.27$ & $1.93 \pm 0.54$ \\
t-ACPD & $28.8 \pm 3.8$ & $15.7 \pm 7.2$ & $14.0 \pm 8.0$ \\
$1 S, 3 R$-ACPD & $9.3 \pm 2.0$ & $6.7 \pm 1.7$ & $5.3 \pm 2.3$ \\
$1 R, 3 S$-ACPD & $126.7 \pm 14.5$ & $45.0 \pm 8.7$ & $35.0 \pm 5.0$ \\
$1 S, 3 S$-ACPD & $>300$ & $>300$ & $>300$ \\
$1 R, 3 R$-ACPD & $>1000$ & $>300$ & $>300$
\end{tabular}

IP production in LLC-PK 1 cells expressing mGluR $1 \mathrm{a}$, mGluR5a, or mGluR5b was determined after 30 min stimulation with the indicated agonists at various concentrations. The $\mathrm{EC}_{50}$ values $(\mu \mathrm{M})$ were determined graphically. Each individual experiments were performed in triplicates as shown on Figure 10, and data are means \pm SEM of three to five independent determinations.
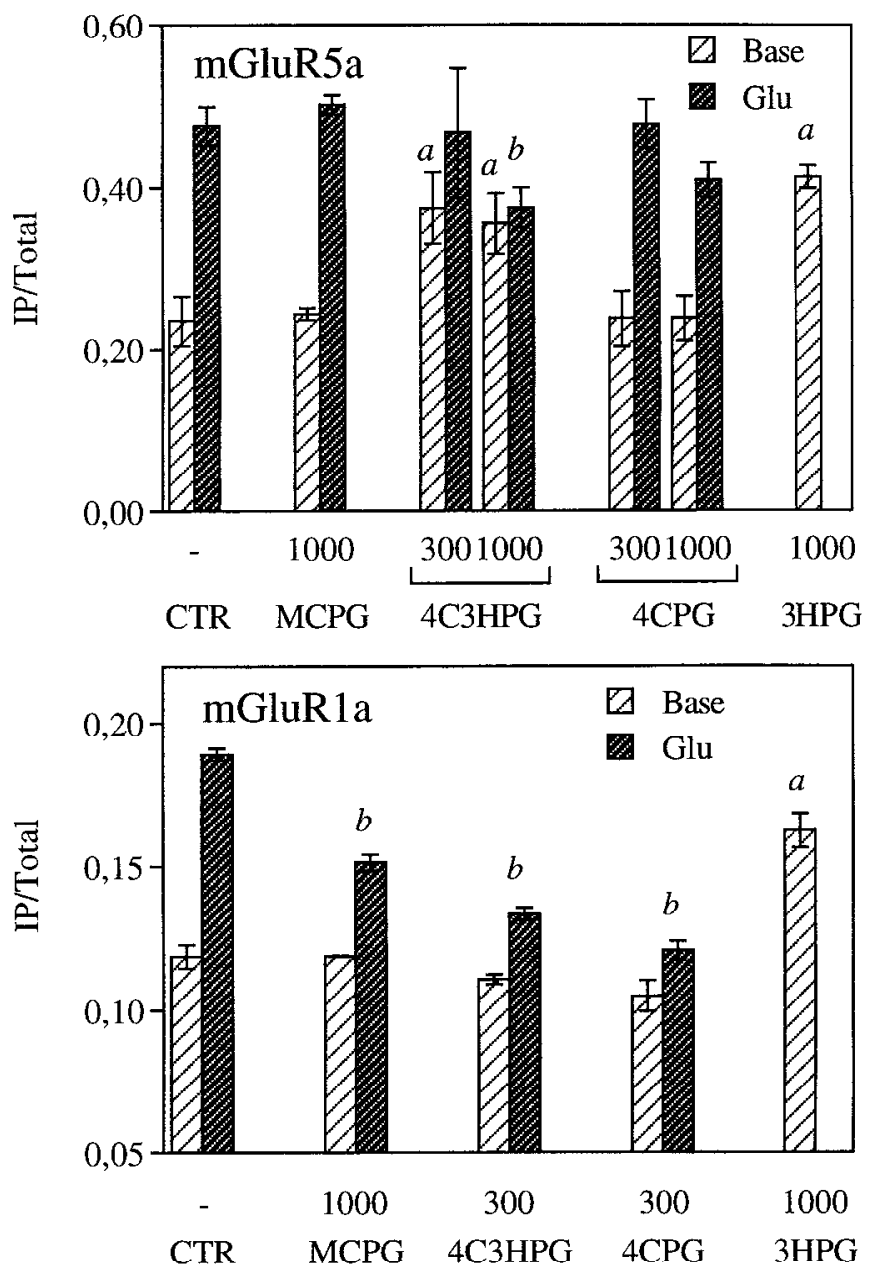

Figure 11. Effect of phenylglycine derivatives on mGluR5a and mGluR1a. ${ }^{3} \mathrm{H}$-inositol-labeled LLC-PK1 cells transiently expressing mGluR5a or mGluR la were preincubated for $10 \mathrm{~min}$ in Krebs medium containing $10 \mathrm{mM} \mathrm{LiCl}$ alone or in the presence of the indicated concentration $(\mu \mathrm{M})$ of the phenylglycine derivatives. Cells were incubated for a further $30 \mathrm{~min}$ in the same medium (light bars) or after addition of $10 \times$ concentrated Glu solution (final concentration $10 \mu \mathrm{M}$; dark bars). $a$, Statistically different from the control base; $b$, statistically different from the control Glu ( $t$ test, $p<0.01$ ). Results are expressed as the ratio of ${ }^{3} \mathrm{H}$-IP produced over total radioactivity in the membranes, and are means \pm SEM or triplicate determinations from a typical experiment. 
Table 2. Summary of the properties of mGluR1 and mGluR5 splice variants

\begin{tabular}{|c|c|c|c|c|c|}
\hline & \multicolumn{5}{|c|}{ mGluR } \\
\hline & la & $1 b$ & lc & $5 a$ & $5 b$ \\
\hline Long C-terminal & + & - & - & + & + \\
\hline Rapid and transient & + & - & - & + & + \\
\hline Increase basal & + & - & - & + & + \\
\hline Adenylyl cyclase & + & - & - & + & + \\
\hline $\begin{array}{l}\text { Expression in patches at the } \\
\text { plasma membrane }\end{array}$ & + & - & - & + & + \\
\hline
\end{tabular}

measured to be too low to activate the receptor. Morcover, the Glu degrading enzyme GPT does not diminish basal PLC activity. This effect may result from a change in the amount of PLC or of other factors regulating PLC activity, due to the presence of mGluR5. This is, however, not the consequence of the coupling of this receptor to PLC since overexpression of other receptors that have even stronger PLC activity such as the PACAP or the V1 vasopressin receptors does not increase basal PLC activity in these cells (Spengler et al., 1993). This increase in PLC basal activity resulting from mGluR5 expression is also observed in HEK293 cells, indicating that this is not a particularity of LLC-PK 1 cells (unpublished results). It is therefore possible that mGluR5a and $b$ have a high intrinsic activity in the absence of agonist. Recently, mutated receptors with high intrinsic activity have been described (for a review, see Coughlin, 1994), and more careful analysis revealed that many wild type receptors including $\delta$ opioid receptors (Costa and Hertz, 1989), the $\alpha 1 \mathrm{~B}, \alpha 2$ and $\beta 2$-adrenergic receptors (Kjelsberg et al., 1992; Chidiac et al., 1994; Samama et al., 1994; Tian et al., 1994), the 5HT2c receptor (Barker et al., 1994), and muscarinic receptors (Hilf and Jakobs, 1992) have intrinsic activity, even in their normal environment (Hilf and Jakobs, 1992). It has been proposed that even in the absence of agonist, receptors exist in two conformational stages, an inactive stage $R$ and an active stage $\mathrm{R}^{*}$. The action of the agonist may then be simply to change the equilibrium constant between these two stages

In LLC-PK1 cells, both mGluR5a and mGluR5b stimulate cAMP formation. A similar effect was also observed with mGluR la but not with mGluR lb. In CHO cells stably expressing mGluRs, stimulation of adenylyl cyclase was observed with mGluR 1a (Aramori and Nakanishi, 1992) but not with mGluR5a (Abe et al., 1992), indicating that mGluR5 under certain conditions can specifically activate PLC. It is possible that in LLCPK1 cells the increased production of cAMP is a consequence of the activation of PLC. In agreement with this hypothesis is our observation that the IP and cAMP production stimulated by mGluR5a or b are equally sensitive to $\mathrm{PdBu}$ and staurosporine. However, activation of mGluRIb, that also stimulates IP production in these cells, does not increase cAMP production. More work is therefore required to confirm a possible direct coupling of mGluR5 splice variants to adenylyl cyclase via activation of Gs proteins.

Taken together, these results indicate that the two mGluR5 variants possess all the functional characteristics of mGluRla (Table 2), strongly suggesting that the long C-terminal domain of these 3 receptors, although having low homology, may have similar roles. It is actually possible that this long C-terminal domain allows the receptor to be expressed at a higher density at the cell surface, so that the high basal activity and the coupling to adenylyl cyclase can be detected. This possibility cannot actually be tested due to the absence of radioactive ligands with high enough affinity to do binding experiments on intact cells. Another possibility is that the long C-terminal domain facilitates the coupling of the receptor to PLC and allows it to couple to adenylyl cyclase. In agreement with this hypothesis is the observation that the truncated receptors mGluR Ib and mGluRlc induce slowly generating oscillatory responses which are never observed with mGluR 1a, mGluR5a or b, even when these proteins are expressed at a low density when small amount of cRNA are injected. A similar difference in the shape of the $\mathrm{Ca}^{2+}$ signal induced in oocytes has been described with different muscarinic receptors (Lechleiter et al., 1990), and with splice variants of the PACAP receptors (Spengler et al., 1993). More recently, point mutations in the domains of the $m 3$ receptor involved in the activation of G-proteins have been shown to change the shape of the $\mathrm{Ca}^{2+}$ response from fast and transient to slow and oscillatory, without major changes in the receptor density (Kunkel and Peralta, 1993). Taken together, these observations strongly suggest that the shape of the $\mathrm{Ca}^{2+}$ signal is dependent on the coupling efficacy of the receptor to PLC rather than to its level of expression per se. It is also possible that this functional characteristic is due to the clustering of the receptors, as suggested by the patches observed on the plasma membrane of cells transfected with mGluR la, 5a, or $5 b$.

The pharmacological profile of mGluR5a and mGluR5b were found to be identical, indicating that the presence of the $32 \mathrm{ami}-$ no acid fragment in mGluR5b does not modify the ligand binding site. Accordingly, the Glu recognition site in mGluRs has been located in the large $\mathrm{N}$-terminal extracellular domain (O'Hara et al., 1993; Takahashi et al., 1993). Even though this domain is highly homologous between mGluR1 and mGluR5 (Abe et al., 1992), we observed interesting pharmacological differences between these two receptors. First, most agonists but Glu have a higher potency on mGluR5 than on mGluR1. Among these agonists, Quis is 10 times more potent on mGluR5 than on $m$ GluR1, in agreement with the different $\mathrm{EC}_{50}$ values reported for Quis in stimulating IP formation in neurons. For example, Quis is more potent in cortical and striatal neurons (Sladeczek et al., 1985; Patel et al., 1990; Manzoni et al., 1991), likely expressing more mGluR5 than mGluR1 (Masu et al., 1991; Abe et al., 1992; Prézeau et al., 1994), than in cerebellar granule cells (Nicoletti et al., 1986; Suzdak et al., 1993) which express only mGluR1 (Masu et al., 1991; Abe et al., 1992; Prézeau et al., 1994). Moreover, whereas the phenylglycine derivatives MCPG, 4CPG and 4C3HPG are full competitive antagonists at mGluR1, only 4C3HPG slightly inhibits Glu stimulation of IP production in LLC-PK 1 cells expressing mGluR5. However, 4C3HPG on its own stimulates IP production in mGluR5 expressing cells indicating that it is a partial agonist on this mGluR subtype. Interestingly, 4C3HPG has been described as a partial agonist at PLC-coupled mGluRs in rat cortical slices (Birse et al., 1993). In the brain, these three phenylglycine derivatives do not antagonize t-ACPD-induced inhibition of a $\mathrm{K}$-channel in nucleus tractus solitarius neurons, an effect likely mediated by a PLCcoupled mGluR (Glaum et al., 1993). In pyramidal neurons of the CA1 field of the hippocampus which express more mGluR5 than mGluRl mRNA (Masu et al., 1991; Abe et al., 1992). MCPG does, however, antagonize the L-ACPD-induced inhibition of spike accommodation, an effect likely mediated by PLC- 
coupled mGluRs (Bashir et al., 1993). Such an effect is however not observed by other authors (Chinestra et al., 1993).

In conclusion, no functional differences have been noticed between mGluR5a and mGluR5b. It is however possible that the additional sequence present in mGluR5b plays some role in the coupling to other transduction mechanisms not analyzed here, such as the regulation of $\mathrm{Ca}^{2+}$ or $\mathrm{K}^{+}$-channels. Interestingly, mGluR5a and mGluR5b possess all the functional properties of mGluR la, suggesting that the long $\mathrm{C}$-terminal intracellular domain present only in these receptors, although not well conserved, is likely to be involved in their specific functional properties. Finally, although the ligand recognition sites of mGluR5a/b and mGluR $l a$ are highly conserved, these receptors have different pharmacology.

\section{References}

Abe $T$, Sugihara $H$, Nawa $H$, Shigemoto R, Mizuno N, Nakanishi $S$ (1992) Molecular characterization of a novel metabotropic glutamate receptor mGluR5 coupled to inositol phosphate/ $\mathrm{Ca}^{2+}$ signal transduction. J Biol Chem 267:13361-13368.

Aramori I, Nakanishi S (1992) Signal transduction and pharmacological characteristics of a metabotropic glutamate receptor, mGluR I, in transfected CHO cells. Neuron 8:757-765.

Barker EL, Westphal RS, Schmidt D, Sanders-Bush E (1994) Constitutive active 5-hydroxytryptamine $2 \mathrm{c}$ receptors reveal novel inverse agonist activity of receptor ligands. J Biol Chem 269:11687-11690.

Bashir ZI, Bortolotto ZA, Davies CH, Berreta N, Irving AJ, Seal AJ, Henley JM, Jane DE, Watkins JC, Collingridge GL (1993) Induction of LTP in the hippocampus needs synaptic activation of glutamate metabotropic receptors. Nature 363:347-350.

Birse EF, Eaton SA, Jane DE, Jones PLSJ, Porter RHP, Pook PC-K, Sunter DC, Udvarhelyi PM, Wharton B, Roberts PJ, Salt TE, Watkins JC (1993) Phenylglycine derivatives as new pharmacological tools for investigating the role of metabotropic glutamate receptors in the central nervous system. Neuroscience 52:481-488.

Chidiac P, Hebert TF, Valiquette M, Dennis M, Bouvier M (1994) Inverse agonist activity of $\beta$-adrenergic antagonists. Mol Pharmacol 45:490-499.

Chinestra P, Aniksztejn L. Diabira D. Ben-Ari Y (1993) (RS)- $\alpha$-methyl4-carboxyphenylglycine neither prevents induction of LTP nor antagonizes metabotropic glutamate receptors in CA1 hippocampal neurons. J Neurophysiol 70:2684-2689.

Chomezynski P, Sacchi N (1987) Single-step method of RNA isolation by acid guanidinium thiocyanate-phenol-chloroform extraction. Anal Biochem 162:156-159.

Cockcroft S, Thomas GMH (1992) Inositol-lipid-specific phospholipase $\mathrm{C}$ isozymes and their differential regulation by receptors. Biochem J 288: I-14.

Costa T, Hertz A (1989) Antagonists with negative intrinsic activity at $\delta$ opioid receptors coupled to GTP-binding proteins. Proc Natl Acad Sci USA 86:7321-7325.

Coughlin SR (1994) Expanding horizons for receptors coupled to G proteins: diversity and disease. Curr Biol 6:191-197.

Curry K, Peet MJ, Magnuson DSK, McLennan H (1988) Synthesis, resolution, and absolute configuration of the isomers of the neuronal excitant I-amino-1,3-cyclopentanedicarboxylic acid. J Med Chem 31: 864-867.

Didier M, Roux P, Piechaczyk M, Mangeat P, Verrier B, Devilliers G, Bockaert J, Pin J-P (1992) Long-term expression of c-fos protein during the in vitro maturation of cerebellar granule cells induced by potassium or NMDA. Mol Rrain Res 12:249-258.

Glaum SR, Sunter DC, Udvarhelyi PM, Watkins JC, Miller RJ (1993) The actions of phenylglycine derived metabotropic glutamate receptor antagonists on multiple ( $S, 3 R$ )-ACPD responses in the rat nucleus of the tractus solitarius. Neuropharmacology 32:1419-1425.

Hilf G, Jakobs KH (1992) Agonist-independent inhibition of G-protein activation by muscarinic acetylcholine receptor antagonists in cardiac membranes. Eur J Pharmacol 225:245-252.

Hirono C, Ito I, Sugiyama H (1987) Neurotensin and acetylcholine evoke common responses in frog oocytes injected with rat brain messenger ribonucleic acid. J Physiol (Lond) 382:523-535.
Hollmann M, Heinemann S (1994) Cloned glutamate receptors. Annu Rev Neurosci 17:31-108.

Houamed KM, Kuijper JL, Gilbert TL, Haldeman BA, O'Hara PJ, Mulvihill ER, Almers W, Hagen FS (1991) Cloning, expression, and gene structure of a G-protein-coupled glutamate receptor from rat brain. Science 252:1318-1321.

Journot L, Spengler D, Pantaloni C, Dumuis A, Sebben M, Bockaert J (1994) The PACAP receptor: an example of functional diversity among $\mathrm{G}$ protein-coupled receptors generated by alternative splicing. Semin Cell Biol 5: in press.

Kjelsberg MA, Cotecchia S, Ostrowski J, Caron MG, Lekkowitz RJ (1992) Constitutive activation of the $\alpha 1 \mathrm{~B}$-adrenergic receptor by all amino acid substitutions at a single site: evidence for a region which constrains receptor activation. J Biol Chem 267:1430-1433.

Kunkel MT, Peralta EG (1993) Charged amino acids required for signal transduction by the $\mathrm{m} 3$ muscarinic acetylcholine receptor. EMBO J $12: 3809-3815$.

Lechleiter J, Hellmiss R, Duerson K, Ennulat D, David N, Clapham D, Peralta E (1990) Distinct sequence elements control the specificity of $\mathrm{G}$ protein activation by muscarinic acetylcholine receptor subtypes. EMBO J 9:4381-4390.

Lechleiter J, Girard S, Clapham D, Peralta E (1991) Subcellular patterns of calcium release determined by $\mathrm{G}$ protein-specific residues of muscarinic receptors. Nature 350:505-508.

Manzoni O, Fagni L, Pin JP, Rassendren F, Poulat F, Sladeczek F and Bockaert J (1990) (Trans)-1-amino-cyclopentyl-1,3-dicarboxylate stimulates quisqualate phosphoinositide-coupled receptors but not ionotropic glutamate receptors in striatal neurons and Xenopus oocytes. Mol Pharmacol 38:1-6.

Manzoni OJJ, Poulat F, Do E, Sahuquet A, Sassetti I, Bockaert J, Sladeczek FAJ (1991) Pharmacological characterization of the quisqualate receptor coupled to phospholipase $\mathrm{C}(\mathrm{Qp})$ in striatal neurons. Eur J Pharmacol (Mol Pharmacol Sec) 207:231-24l.

Masu M, Tanabe Y, Tsuchida K, Shigemoto R, Nakanishi S (1991) Sequence and expression of a metabotropic glutamate receptor. $\mathrm{Na}-$ ture 349:760-765.

Mengot G, Vilaro MT, Niznik HB, Sunahara RK, Sceman P, O'Dowd BP, Palacios JM (1991) Visualization of a dopamine D1 receptor mRNA in human and rat brain. Mol Brain Res 10:185-191.

Minakami R, Katsuki F, Sugiyama H (1993) A variant of metabotropic glutamate receptor subtype 5: an evolutionally conserved insertion with no termination codon. Biochem Biophys Res Commun 194:622627.

Monaghan DT, Bridges RJ, Cotman CW (1989) The excitatory amino acid receptors: their classes, pharmacology and distinct properties in the function of the central nervous system. Annu Rev Pharmacol Toxicol 29:365-402

Nakajima Y, Iwakabe H, Akazawa C, Nawa II, Shigemoto R, Mizuno $\mathrm{N}$, Nakanishi S (1993) Molecular characterization of a novel retinal metabotropic glutamate receptor mGluR6 with a high agonist selectivity for L-2-amino-4-phosphonobutyrate. J Biol Chem 268: I I86811873.

Namba T, Sugimoto Y, Negishi M, Irie A, Ushikubi F, Kakizuka A, Ito S, Ichikawa A, Narumiya S (1993) Alternative splicing of C-terminal tail of prostaglandin E receptor subtype EP3 determines G-protein specificity. Nature 365:166-170.

Negishi M, Sugimoto Y, Irie A, Narumiya S, Ichikawa A (1993) Two isoforms of the prostaglandin E receptor EP3 subtype: different COOII-terminal domains determining sensitivity to agonist-induced desensitization. J Biol Chem 268:9517-9521.

Nicoletti F, Wroblewski JT; Novelli A, Alho H, Guidotti A, Costa E (1986) The activation of inositol phospholipid metabolism as a signal-transduction system for excitatory amino acids in primary cultures of cerebellar granule cells. J Neurosci 6:1905-1911.

O'Hara PJ, Sheppard PO, Thøgersen H, Venezia D, Haldeman BA, McGrane V, Houamed KM, Thomsen C, Gilbert TL, Mulvihill ER (1993) The ligand-binding domain in metabotropic glutamate receptors is related to bacterial periplasmic binding proteins. Neuron 11: $41-52$.

Okamoto N, Hori S, Aka/awa C, Hayashi Y, Shigenolo R, Mizuno N, Nakanishi S (1994) Molecular characterization of a new metabotropic glutamate receptor mGluR7 coupled to inhibitory cyclic AMP signal transduction. J Biol Chem 269:1231-1236.

Patel J, Moore WC, Thompson C, Keith RA, Salama Al (1990) Char- 
acterization of the quisqualate receptor linked to phosphoinositide hydrolysis in neurocortical cultures. J Neurochem 54:1461-1466.

Pickering DS, Thomsen C, Suzdak PD, Fletcher EJ, Robitaille R, Salter MW, MacDonald JF, Huang X, Hampson DR (1993) $\Lambda$ comparison of two alternatively spliced forms of a metabotropic glutamate receptor coupled to phosphoinositides turnover. J Neurochem 61:8592.

Pin J-P, Duvoisin R (1995) The metabotropic glutamate receptors: structure and functions. Neuropharmacology 34:1-26.

Pin J-P, Weiss S, Sebben M, Kemp D, Bockaert J (1986) Release of endogenous amino acids from striatal neurones in primary culture. $\mathrm{J}$ Neurochem 47:594-603.

Pin J-P, Waeber C, Prézeau L, Bockaert J, Heinemann SF (1992) Alternative splicing generates metabotropic glutamate receptors inducing different patterns of calcium release in Xenopus oncytes. Pros Natl Acad Sci USA 89:10331-10335.

Pin J-P, Joly C, Heinemann SF, Bockaert J (1994) Domains involved in the specificity of $\mathrm{G}$ protein activation in phospholipase $\mathrm{C}$ coupled metabotropic glutamate receptor. EMBO J 13:342-348.

Prézeau L, Carette J, Helpap B, Curry K, Pin J-P, Bockaert J (1994) Pharmacological characterization of metabotropic glutamate receptors in several types of brain cells in primary cultures. Mol Pharmacol 45:570-577.

Romano C, Sesma MA, MacDonald C, O'Malley K, van den Pol AN, Olney JW (1994) Distribution of metabotropic glutamate receptor mGluR5 immunoreactivity in rat brain. J Comp Neurol, in press.

Samama P, Pei G, Costa T, Cotecchia S, Lefkowitz RJ (1994) Negative antagonists promote an inactive conformation of the $\beta 2$-adrenergic receptor. Mol Pharmacol 45:390-394.

Saugstad JA, Kinzie JM, Mulvihill ER, Segerson TP, Westbrook GL
(1994) Cloning an expression of a new member of the L-2-amino-4phosphonobutyric acid-class of metabotropic glutamate receptors. Mol Pharmacol 45:367-372.

Simoncini L, Haldeman BA, Yamagiwa T, Mulvihill E (1993) Functional characterization of metabotropic glutamate receptor subtypes. Biophys J 64:A84.

Sladeczek F, Pin J-P, Récasens M, Bockaert J, Weiss S (1985) Glutamate stimulates inositol phosphate formation in striatal neurones. Nature 317:717-719.

Spengler D, Waeber C, Pantaloni C, Holboer F, Bockaert J, Seeburg PH, Journot L (1993) Differential signal transduction by five splice variants of the PACAP receptor. Nature 365:170-175.

Sugimoto Y, Negishi M, Hayashi Y, Namba T, Honda A, Watabe A, Hirata M, Narumiya S, Ichikawa A (1993) Two isoforms of the EP3 receptor with different carhoxy-terminal domains: identical ligand binding properties and different coupling properties with $\mathrm{Gi}$ proteins. J Biol Chem 268:2712-2718.

Suzdak PD, Sheardown MJ, Honoré T (1993) Characterization of the metabotropic glutamate receptor in mouse cerebellar granule cells: lack of effect of 2,3-dihydroxy-6-nitro-7-sulphamoylbenzo(F)-quinoxaline (NBQX). Eur J Phannacol (Mol Pharmacol Sec) 245:215220.

Takahashi K, Tsuchida K, Tanabe Y, Masu M, Nakanishi S (1993) Role of the large extracellular domain of metabotropic glutamate receptors in agonist selectivity determination. J Biol Chem 268:19341-19345.

Tanabe Y, Masu M, Ishii T, Shigemoto R, Nakanishi S (1992) A family of metabotropic glutamate receptors. Neuron 8:169-179.

Tian W-N, Duzic E, Lanier SM, Deth RC (1994) Determinants of the $\alpha 2$-adrenergic receptor activation of $\mathrm{G}$ proteins: evidence for a precoupled receptor/G protein state. Mol Pharmacol 45:524-531. 